\title{
The Effects of Chieftaincy and Land Conflicts on the Socio-political Development of Northern Ghana
}

\author{
Francis Issahaku Malongza Bukari \\ Faculty of Integrated Development Studies \\ University for Development Studies, Ghana \\ E-mail: bfrancis@uds.edu.gh
}

Stephen Bugu Kendie

Institute for Development Studies

University of Cape Coast, Ghana

E-mail: stephenkendie@gmail.com

Mohammed Sulemana (Corresponding author)

Faculty of Planning and Land Management

University for Development Studies, Ghana

E-mail: mohammedsule88@yahoo.co.uk

Sylvester Zackaria Galaa

Faculty of Integrated Development Studies

University for Development Studies, Ghana

E-mail: sylvestergalaa@yahoo.com

Received: January 4, 2017 Accepted: February 20, 2017 Published: March 29, 2017

doi:10.5296/ijssr.v5i1.11008 URL: http://dx.doi.org/10.5296/ijssr.v5i1.11008 


\section{Abstract}

This paper assesses the effects of inter-ethnic chieftaincy and land conflicts on the socio-political development of northern Ghana. The knowledge gap the study sought to fill is the use of theoretical antecedents to illustrate that conflicts have some merits for socio-political development and that conflict theories equally depict solutions to conflicts. Methodologically, the study makes use of content analysis of secondary data, by following the tenets of the realistic group conflict theory. Examples were drawn from the Konkomba, Gonja, Nanumba, Dagomba, Kusasi, Mo and the Sissala disputes of emancipation. It was revealed that major positive effects of the conflicts include improvement in the decision-making processes on community development issues, strengthening of inter-ethnic unity and helping to redeem the identity of a group. The destruction of life and property is the major demerit. It was recommended that civic education on the causes and effects of the conflicts by authentic participation of potential disputants could provide a more sustainable way of preventing conflict.

Keywords: Realistic Group Conflict Theory, inter-ethnic conflict, land, chieftaincy, northern Ghana

\section{Background}

This paper examines the state of chieftaincy and land conflicts and their effects on the socio-political development of northern Ghana. In view of its association with such concepts as argument, fighting, antagonism, misunderstanding, opposition, incompatibility and hostility, conflict has generally been thought of in negative terms. This is because people usually become aware of a conflict only when it has escalated and caused confusion, disorder or destruction (Coser, 1956; Botchwey, 2006). On the contrary, Robinson (1972) and Jacquel (2007) argue that conflict also has some merits, for example in improving the quality of group decisions; helping to define community development issues; and restoring the dignity and respect to previously marginalised groups (Botchwey, 2006).

Despite these and many other merits of conflict in social development, the lack of understanding of its positive dimensions has been contributory to the dominance of the negative ideas about conflict. In northern Ghana (which comprises the Northern, Upper East and Upper West Regions) this is particularly so among the majority or chiefly ethnic groups. The majority groups refer to the ethnic groups which hold traditional political power, while the minority ethnic groups constitute the subgroup or subordinate tribes (Gad, 2003; Chen, 2010). In this study, the majority ethnic groups include the Dagomba, Gonja, Nanumba and Mamprusi, which historically gained traditional political power over the previously non-chiefly or subgroups in neighbouring territories, such as the Konkomba, Mo, Nawuri and Kusasi, by conquest (Mahama, 2010).

The major trigger of conflict between the majority and minority groups is usually by expressions of desire for emancipation by the latter groups for self-rule and ownership of land demarcated by territorial boundaries (Hippolyt, 2003). The apparent emergence of conflicts between the two groups over the demands of the minorities finds explanations in various 
theories of conflict, such as the Psycho-cultural Conflict Theory, the Greed-grievance Theory, the Economic Conflict Theory and the Realistic Group Conflict Theory. All these do not only explain the causes of conflict, but also explain how equilibrium could be reached among previously antagonistic groups.

The Psycho-Cultural Conflict Theory for instance, contends that differences in identity based on people's ethnic origin and culture is one of the most important explanations for violent conflicts. Such conflicts aim to redeem the self-esteem and dignity of a cultural group (Ross, 2001). Identity related conflicts often result to violent, destructive and long lasting conflicts that are difficult to resolve (Tsikata \& Seini, 2004). In terms of reaching equilibrium by identity related disputants, Kagwanja and Hagg (2007), posit that such conflicts result from conceptual differences about identity between the majority and the minority, and that any effort towards the reconceptualisation of identity by the groups involved could lead to sustainable peace and reconciliation. Anything outside the inter-group consensus could de-escalate the conflict, but the conflict will remain latent (Zartman, 1985/1989).

Furthermore, according to Collier and Hoeffler (2002), the Greed-grievance Theory explains that preferences and constraints dictate the circumstances that favor rebellions. It states further that, societies can be more prone to conflict because preferences for rebellion (powerlessness and lack of access to resources -grievances) are unusually strong, or because constraints on rebellion (e.g. power and greater control over resources-greed) are unusually weak. Thus, the greed side of the theory implies that majorities in a conflict are motivated to defend and maintain their desires for power and control over resources. This is usually against the interests of a rebelling minority group, who lack power and control over resources on the basis of identity e.g. ethnicity, as the grievance side of the theory. Ganesan and Vines (2004) and Collier (2006) contend that an understanding of the influence of the dynamics of greed and grievance on the state of conflict, should necessitate curbing rebel financing, robust military presence, equity in power sharing and a focus on economic growth projects for the rebelling or vulnerable regions. On the other hand, Awedoba (2010) argues that the encouragement of inter-group conflict resolution procedures involving collaboration towards power sharing in particular, rather than external control offer the best solutions.

With the Economic Theory of Conflict, Collier and Rohner (2007, cited in Mzumara, 2012), argue that the most important motivation of conflict is the ability of the predator group to sustain itself in terms of military and financial capabilities. These determine the likelihood of a country experiencing internal violent conflicts or civil war. Collier (2006) explains further that in societies where there are perceived grievances by minority group and lust for power by the majority group such that there is social inequality between the groups, a situation known as social deprivation on the part of the minority is said to exist. The risk of conflict occurring depends on the feasibility or the expected economic gains from the conflict by the rebelling minority group (Collier, 2006). Macartan (2003) asserts that economic conflicts over natural resources such as land, and power to control such resources result from poverty on the part of the aggrieved minority and greed by the majority. The author therefore suggests that such understanding should lead to the control of the proliferation of small arms and economic policies that encourage donors to focus on development projects for poverty 
reduction, and the promotion of agricultural production by the state. The recognition of conceptual differences in power should not also necessarily result to violence and chaos by the minority, but rather, a search for alternative sources of power such as the National House of Chiefs and religious leaders as mediators, and the judicial system for the purpose of negations for mutual agreements (Galaa \& Bukari, 2014).

The Realistic Group Conflict Theory also expresses how selfish interests between groups lead to competition for scarce resources (Sidanius \& Pratto, 1999). It explains that parties in conflict with each other identify themselves on the basis of some material and socio-cultural realities. As competition develops and inter-group hostility increases, there emerges a stage where cooperation and reciprocal interaction between the groups are restored. Thus, the realistic group conflict theory anchors on three main elements as the basis of conflict, namely group identity, organisation and competition for scarce resources. A critical view of the inter-ethnic conflicts in northern Ghana under a theoretical lens shows that they are related to issues of identity (ethnicity), power (chieftaincy) and access to resources (e.g. land rights). In other words, they are "struggles over questions of what constitutes authentic local representation, and legitimate land rights" (Jonsson, 2007: 4). The realistic group conflict theory therefore, constitutes a better integrated theory for the explanation of inter-ethnic conflict and conflict resolution, and so incorporates aspects of the other theories discussed in this background. It therefore serves as the overarching theory in this study.

Empirically, despite the relevance of conflict theories in explaining the causes of conflict, the negative and positive effects, and how the destructive aspects of the conflicts could be prevented, there is very little information on such linkages. Scholars such as Awedoba (2010/2014), Hippolyt (2003), and Kendie and Bukari (2012), have variously expatiated on chieftaincy and land disputes in northern Ghana. However, there were no indications of the role of theory in explaining how the outcomes of the resolution processes proved that the destructive stages of the conflicts could have been avoided if knowledge of the theories aided the processes. In a limited case, Kendie and Akudugu (2010), examined the application of the game theory in the management of natural resource conflict. However, the purpose was not to demonstrate that knowledge of the tenets of the theory by the combatants or peacemakers prevented violence and destruction.

The main objective of the study is to develop and use a theoretical approach for the assessment of the effects of the inter-ethnic chieftaincy and land conflicts on the socio-political development of northern Ghana. The justification emanated from the view that whereas it is common to find topics on the merits of conflicts in general terms (See Botchwey, 2006), the lack of scholarly attention on the presentation of some of the benefits of previous ethnic conflicts creates a basis for further enquiry. The research niche this study seeks to fill is therefore to illustrate the place of theory in explaining how some disputes were resolved. It points out that the violence and destruction that resulted from some conflicts could have been avoided by the collective action of the combatants, government agencies, traditional political institutions, and the civil society, if they understood the theoretical trajectory of the conflict.

Methodologically, the study is basically an applied research as it seeks to explain inter-ethnic 
chieftaincy and land conflicts in northern Ghana using the tenets of the Realistic Group Conflict Theory. It draws cases from the Dagomba-Konkomba, Nanumba-Konkomba, Gonja-Konkomba, Gonja-Mo inter-ethnic conflicts of the Northern Region; the Mamprusi-Kusasi conflict of the Upper East Region; and Dagati-Sissala conflict of the Upper West Region. Secondary data from books, journal articles and other internet publications constituted the main sources of data. The study design was retrospective-prospective, with an analytical approach that was basically qualitative and the use of the deductive method. Results were discussed using the content analysis technique for the interpretation of text data.

\section{Theoretical Basis of the Study}

The Realistic Group Conflict Theory was the main theory that gave direction to this study. The relevant epistemological and validation aspects of the theory are discussed below.

\subsection{Epistemological Basis of the Realistic Group Conflict Theory}

The realistic group conflict theory (RGCT) was first named by Donald Campbell and used to describe the nature and dynamics of intergroup conflict over scarce resources (Sidanius \& Pratto, 1999). The basic tenets of the theory and its validation by Muzafer Sherif with his famous Robber's Cave Experiment (see Sherif, Harvey, White, Hood, \&Sherif, 1961) are presented in the sections that follow.

\subsubsection{Basic Premise: Groups Have Their Own Reality}

The main premise of the RGCT is that groups have their own reality. This means that every group has its unique cultural identity and so distinguished from other groups that might be in competition or have the potentials of being in competition for scarce resources with it. Examples include group ethnicity, history, ancestry, values, norms, rules and regulations regarding access to resource use.

\subsubsection{Reality Is Determined by Material Conditions That Exist}

This relates to the idea that the major determinant of group norms, values, rules and regulations regarding access to resources, is the nature of available resources. Thus, where resources are scarce, the incidence of rivalry is high. As such, the culture is shaped in such a way that it imposes restrictions. For example, there could be prohibitions, class formation and ascribed prejudice to some members to the detriment of the interests of others in relation to rights of access to resources. This study examines how the cultures of the chiefly and minority groups are shaped and distinguished from each other, and the associated conflict relating to how the differences affect their material interests.

\subsubsection{Competition (for Limited Resources) Results to Negative Relations}

The definition of group reality on the basis of material conditions, in such a manner that it creates alienation between identified classes, could cause divisiveness and class struggle between the groups. Harmony within the larger group is thus, distorted, causing negative relations as the different classes compete for the scarce resources. For example, if a group is initially identified by a defined territorial boundary, and culture is later manipulated to 
ascribes the right to rule and own land to an identified class of people, this causes class differentiation. What happens if the group subordinated by 'cultural change', later demands the right to rule themselves, is an issue of research interest.

\subsubsection{Cooperation and Reciprocal Interactions; Positive Relations}

This tenet has to do with inter-group competition, where synthesis results. Under this, there emerges some compromise, collaboration, and consensus through mutual agreements. In the context of the RGCT, such a synthesis evolves from the competing groups themselves. Existing literature is often more concerned about the causes and negative effects of inter-ethnic conflicts. Hence, this study examines how conflict could also establish cooperation between groups in northern Ghana.

\subsection{Validation of the RGCT by the Robber's Cave Experiment}

Muzafer Sherif, conducted a validation experiment in Robbers Cave State Park, Oklahoma, with the aim of examining intergroup behavior, involving 22 eleven and twelve-year-old boys who had comparable backgrounds (Sherif et al., 1961). Three stages of the experiment are relevant to this study. They include the in-group formation phase, friction phase and the integration phase. The in-group formation phase is where groups are established, with cultural and material identity. Thus, the paper looks at how the realisation of the prejudices ascribed to the bicephalous tribes in northern Ghana, as a result of their political and military organisations, stimulates the acephalous tribes to also start to undergo socio-cultural and political restructuring to promote their emancipation.

The friction phase is where groups perceive the existence of other groups competing with them for the resources they originally ascribed to themselves and conflicts escalate. Thus, the reactions of the non-chiefly autochthonous ethnic groups to the bicephalous late comers in terms of land acquisition, and its control through traditional authority, as well as the dynamism of the frictional relationships are expatiated.

The integration stage is the stage of intergroup cooperation where conflict ceases. The paper therefore discusses the various stages of the selected inter-ethnic conflicts and the emergent productive outcomes as the disputants come to compromise. The ensuing sections address the objective of the study by elucidating how the RGCT provided a trajectory to the assessment of the effects of inter-ethnic conflicts on the socio-political development of northern Ghana.

\section{Socio-cultural and Political Realities of the Ethnic Groups of Northern Ghana}

In this section, the socio-cultural and political arrangements among the ethnic groups of northern Ghana as components of identity related realities are discussed. The sub-themes, which are also derived from the tenets of the RGCT, are considered below.

\subsection{Determination of In-group Reality on Material Resource Basis}

The determination of in-group reality on material resource basis considers the second tenet of the RGCT which associates group reality with materiality. In northern Ghana, the bi-cephalous groups, using their well-organised political and military institutions were able to 
gain dominion over other acephalous groups who lacked this organisation (Hippolyt, 2003; Mahama, 2010). The initial determination of in-group reality on the basis of land was by the identification of this resource in terms of location and its appropriation by ascription to identified ethnics. Like other ethnic groups, the Mo, Konkomba, Lobi, Sissala and the Kusasi settled in northern Ghana without centralised political systems and lacked local armies of their own. Donkor and Mason (1994) observed that an acephalous society impliedly had no polity or administrative boundary. The bicephalous groups came late, settled among the acephalous groups and imposed political leadership on them, who accepted the conditions by withdrawal to resort to conflict (Martinson, 1994). This was because the bi-cephalous system was strange to the original occupants of the land, who did not foresee the future implications of their being ruled by the new comers (Mahama, 2010).

A hierarchical chieftaincy institution with paramountcy, provincial and sub-chief system was established by the bi-cephalous groups to rule their own people and all other ethnic groups that settled on the lands over which political powers of the rulers covered. This also meant that the ruling class had automatic control over the land. With this agreement initially not provoking violent reactions from the original settlers, they equally agreed to be paying homage to the then new chiefs (Hippolyt, 2003). For instance, in the case of the Kusasi and the Mamprusi, after Naa Atabia of Mamprugu agreed to help the Kusasi in the fight against the raiders of the latter, he subsequently appointed his military leaders to rule the Kusasi communities they protected as traditional chiefs. His son, Prince Ali was also made the Paramount Chief of Bawku. Since then, the paramountcy and other sub-chiefly positions in Kusasi land have been occupied by Mamprusi rulers (Mahama, 2010). There was therefore a situation where the majority and the minority groups lived together as one group but with distinct identities, indicating a possible latent conflict for the future.

In the Upper West Region, an interesting situation is observed between two previously acephalous ethnic groups: The Dagaaba and the Sissala. Greater portions of land belonging to the Lambussie traditional area of the Sissala is being occupied by the Dagaaba in the Lawra District. However, there exists a distinction between traditional political rule and land ownership. In other words, the Dagaaba on Sissala land are ruled by Dagaaba chiefs, while the Sissala rule themselves at the portion of the land they occupy. The Sissala therefore wield the allodial rights to some parts of Dagaaba settled areas, while the latter have usufructuary rights from the Sissala land-owners by consensus (Lentz, 2001). This was another situation that constituted the latent conditions for inter-ethnic conflicts in northern Ghana, which Brukum (2001, cited in DISCAP, 2002) considers as conflicts of emancipation, some of which are discussed in the subsequent sections.

3.2 The Emergence of Competition for Power to Control Land as a Limited Resource and the Associated Negative Relations in Northern Ghana

The third tenet of the RGCT, which states that competition for limited resources results to negative relations, finds relevance at the obvious stage of competitive interaction between the northern ethnic groups, and also reveals the frictional stage of the Robber's Cave experiment. This section of the paper therefore seeks to achieve the aspect of the objective on how theory 
explains the negative consequences of conflict, and how these in turn, influence positive changes for socio-political development.

After the independence of Ghana in 1957, the acephalous groups observed that cultural identity was important since the socio-cultural, socio-political and economic issues of development were now being handled on spatial basis under the local government system. However, this was to the advantage of dominant ethnic groups associated with the space, which is defined by a land area (Hippolyt, 2003). The acephalous groups also observed that apart from spatial identity, ethnic groups are represented by traditional chiefs, who are given due recognition and respect by government officials from the period of colonial rule to the post-independent national government, as well as other independent ethnic groups as a people. They however, lacked this recognition as they were subordinated to the chiefly tribes (DISCAP, 2002). It was therefore obvious that the growth and development of minority tribes raised concerns over the scarcity of land, which influenced the realities of the inter-ethnic competition or tribal wars in northern Ghana.

The northern part of Ghana was chosen for this study because out of a total of 14 ethnic conflicts recorded by Mahama (2010) that took place in Ghana from the 1940s to 2010, seven cases, representing 50 percent, took place in this part of the country, most of which have remained protracted (Kendie \& Bukari, 2012). As shown in Table 1, examples include the land and chieftaincy disputes between the Mamprusi and the Kusasi in the Upper East Region of Ghana, which traces its origin to as far back as the colonial administration in the Gold Coast.

Table 1. Chieftaincy and land conflicts in Northern Ghana

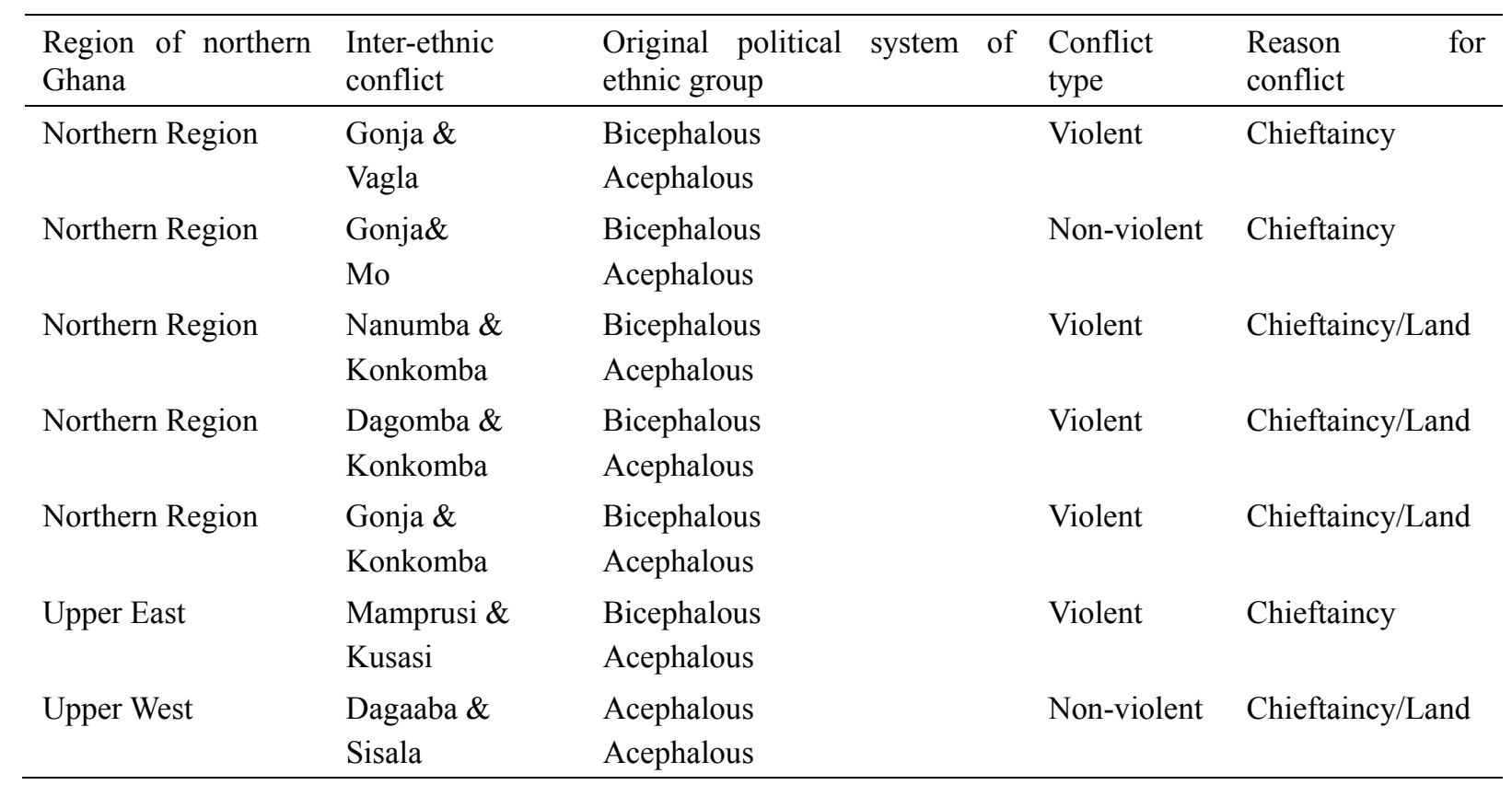

Source: Authors' own construct. 
In the Northern Region, the1994 multi-ethnic targeted land and demand for paramountcy wars of the Konkomba against the Dagomba, the Nanumba and the Gonja is another case in point. While the Dagaaba and Sissala dispute over demarcation of traditional lands during the formation of the Lambussie District, represents a similar situation in the Upper West Region. The non-violent conflict here resulted from the realisation that the Lambussie traditional area was too small to stand alone as a district in terms of Sissala indigenous population, but adequate in terms of land area largely occupied and ruled by Dagaaba chiefs. The dichotomy arose as some Dagaaba communities were considered to be part of the then proposed new Lumbussie-Kami District (Lentz, 2001).

Further evidences of the negative relations could be seen in some of the negative effects of ethnic conflicts on the socio-political development of northern Ghana. These include violence, hostility, destruction of cooperation, and crippling of development efforts.

In terms of violence, many conflicts that attract our attention especially in newspapers, radio, television and other media involve loss of life and property. That is not to say that this happens in all conflicts. However, many of them do (Botchwey, 2006). Losses include the death or injuries caused to people, including innocent children, women and the aged relating to the combatants, as well as military personnel sent out to maintain peace. Also damages are done to buildings, farmlands and other properties such as vehicles. Furthermore, huge sums of money are spent on ammunitions and other equipment; that could have been used for education, health and other development needs. In fact, research findings indicate that between February 1994 and March 1996, the Konkomba fought the Dagomba, Nanumba and the Gonja, in which 2000 people died, 178,000 others displaced, 144 farming villages were destroyed and 18,900 domestic animals and birds were lost (Mahama, 2003; Gati, 2008, cited in Kangsangbata, 2009).

In the case of the Kusasi and Mamprusi conflict in Bawku, Kendie and Bukari (2012) report that the situation has generated cycles of violence in the area for more than eight decades, leading to high levels of violence, insecurity and lawlessness. These discourage investment in the town and retard local livelihood activities including farming. The situation is often exacerbated by frequent imposition of curfew by government forces in attempts to manage the violence. It also led to declines in school and hospital attendance and increased insecurity. The above conditions brought about intra and inter-ethnic disorganisation among the disputants, and other socio-economic effects on all other ethnic communities in northern Ghana.

The above conditions imply that ethnic conflicts in northern Ghana are contributory to the high incidence of poverty in the area (Kendie, 2010). For instance, the fifth and sixth rounds of the Ghana Living Standards Survey reports present the Upper West, Upper East and Northern Regions as the poorest in the country (Ghana Statistical Service, 2008/2014). Ethnic conflict therefore poses a threat to the development of communities in the north. This paper therefore examines why the conflict resolution methods in use have failed, and suggests alternative methods that minimise violence and destruction. In other words, according to the American President Barak Obama, there are productive forms of expressing group 
frustrations, and there are also destructive forms of responding (Matthew, 2014). Alternative methods of conflict resolution are discussed later in the article.

Another negative effect of the conflicts is increase in hostility and divisiveness. Emotions are usually stirred during conflict situations and these include bitterness, hostility and divisiveness. These may happen where conflicts develop such that emotions lead to bitter exchanges between the disputants (Botchwey, 2006). Thus, until the periods between 1940 and 1994, the Dagomba and the Konkomba, the Mamprusi and the Kusasi; the Gonja and the Mo; and the Sissala and Dagaaba, lived in peace with each other sharing common environments, resources and common aspirations from the benefits of development, which they collectively worked for (Mahama, 2010). With the emergence of the chieftaincy conflicts or the demarcation of political administrative boundaries for the purpose of local governance, the relationship between the parties grew bitter to the extent that they did not want to set eyes on, or associate with each other. This actively created division within their ranks.

The above conditions cause intra and inter-ethnic community development activities to suffer because the affected groups cannot present a united front to pursue common objectives for collective development. As a result, things that could be done within a short time have to go through lengthy procedures or may not be done at all. This could happen either within the same ethnic group, such as what happened among the Konkombas over the rotation of the position of the paramount chief after they were granted the autonomy to rule themselves by Ya Naa Yakubu Andani II (Mahama, 2010), or between one ethnic group and opposing parties as discussed earlier.

Although the Sissala-Dagaaba encounter over the demarcation of the Lambussie-Kami District boundaries did not grow to very violent and destructive situations, due to the effective management of the conflict, the confusion led to threats by the Sissala to cease their lands from Dagaaba settlers if the latter refused to join their district after being recognised as such by the National Development Planning Commission. The initial resistance by the Dagaaba was on the condition that they would be cut off from the traditional area over which their Dagaaba paramount chiefs exercised control (Lentz, 2002). This was a sign of possible alienation and divisiveness the conflict could erupt into. Generally, the dispute delayed the formation of the Lambussie-Kami District until 2008, and thus hindered the socio-political development process.

In addition, inter-ethnic conflicts lead to destruction of inter-ethnic cooperation. Development involves cooperation or working together to achieve goals and objectives for a defined target group or beneficiaries. In fact, if any agency or development organisation has enough reason to believe that members of a multi-ethnic community or group are not willing to cooperate in a project activity due to unhealthy relationships between them, they are sure to abandon them and find another partner (Botchwey, 2006). For instance, when the judicial system, the National House of Chiefs and the Civil Society among others, failed to resolve the conflicts between the Dagomba and the Konkomba in the Northern Region; and the Kusasi and the Mamprusi in the Upper East Region over paramountcy and territorial boundary demarcation 
issues, the interests of the institutions to continue the adjudication and mediation roles were lost. The violent conflicts that continued among the affected groups posed development problem to many local communities and have driven away many development partners. Such conflicts could have been brought under control if the disputants were educated to avoid the conflict and accommodate the situations, as remedial conflict management styles (Hizkias, 1999).

Finally, inter-ethnic conflicts cripple development efforts. Conflict may make a community or group unable to act or function, and thus paralysing it. This is the ultimate cost that a conflict may exact on a community or group (Botchwey, 2006). Nothing works, and people and organisations are reluctant to enter the community or work with the group. Sometimes the use of state power through the military may involve the imposition of 24 hour curfews, prohibiting businessmen, farmers and other development project activities, which come to a standstill. For instance Kpandai, a district capital, remained for more than a decade without government's development assistance, and no new development projects, following the Gonja-Konkomba War of 1994 (Mahama, 2010).

Bawku has also experienced a series of curfews between 2009 and 2010 over its chieftaincy dispute between the Mamprusi and the Kusasi. This has affected education as trained teachers either transfer out, or refuse postings to the area; impedes access to health services due to insecurity to travel to health facilities; cripples the local economy through declining business and other livelihood activities such as farming; and causes out-migration of the youth (See Kendie \& Bukari, 2012). A region could easily degenerate due to conflicts, when deliberate efforts are not made to deal with them, and bring people together to think and work for peace and development, especially through the adoption of collaborating, negotiation and mediation.

\section{Cooperation and Reciprocal Interactions after Conflict Within and Among Ethnic Groups in Northern Ghana}

This stage of the analysis is linked to positive effects of conflict and sustainable solutions, dictated by theoretical provisions. The subsections below present the details.

\section{Helping to Put Community Development Issues in Order}

According to Schumpeter (1950), conflict is not all that bad since it brings about creative destruction. This means that conflict causes the destruction of an old order and the creation of a new order. In line with this, Botchwey (2006) explains that conflicts present opportunities for issues to be clarified, re-defined and sharpened. This may happen where a disagreement over procedures or some issues call for re-interpretation and clear definitions to remove ambiguities about meanings. Authorities and experts may be involved in this exercise.

By carefully handling the conflict management process as above, the different ethnic groups of the same community or different communities come to a clearer, better understanding of the issues at stake. This may provide a better shared vision and create renewed energy for joint activities. For example, the desire for freedom from Gonja rule by the Mo in the Bole District of the Northern Region, led to conflict between the two groups, but which was 
resolved by adjudication to give the Mo their traditional political freedom from the Gonja to own and exercise political control over their own land (Hippolyt, 2003). Also, the final establishment of the Lambussie-Kami District in 2008 was achieved under similar conditions as described above. There was therefore conflict cessation through the combined effects of negotiation, arbitration and adjudication. This was the reason why former Chief Justice Acquah of Ghana, argued that best conflict resolution procedures should involve the modern and traditional systems, since any external intervention alone could leave some group dissatisfied and thus, implying a latent conflict in some future time (Acquah, 2006, cited in Awedoba, 2010). Thus, the political freedom won by the Mo resulted from the conflict with the Gonja. The creative destruction character of the outcome is explained by the fact that the Mo people of Bamboi are no longer ruled by the Bole Wura (Chief of Bole).

\subsection{Improvement of Decision-Making on Development Issues}

Conflict may improve decision-making processes in inter and intra-ethnic communities and groups (Awedoba, 2010). Dissatisfaction with existing decision-making procedures may be a source of ethnic conflict. Ethnic groups and structures which were formerly not involved in deliberations or in the making of decisions that affect their lives may now be included. Procedures turn out to be clearly defined in order to avoid conflicts. Thus, when any issue emerges for resolution, people are already aware of what procedures to follow to seek redress.

The above situation could lead to an improvement in the decision-making process at the intra and inter-ethnic community levels. For instance, the cultural inconsistencies between the Konkomba/ Nanumba, the Konkomba/ Dagomba and the Konkomba/Gonja made the Konkomba dissatisfied with the decision-making process and adjudication of their intra ethnic minor disputes by the chiefs of the majority tribes. This made the Konkomba Youth Association (KOYA) to influence Konkomba settlements to elect leaders to lead in decision-making processes and settle minor disputes among smaller groups (Mahama, 2010).

There were also demands to have a Konkomba Traditional Council, as well as the representation of Konkomba Chiefs in the Regional and National Houses of Chiefs (Sulemana, 2009). These decisions led to violent clashes between the Konkomba and the chiefly tribes in view of the perceived breach of the conditions for the adjudication of disputes and decision-making procedures in their relationships. However, the change that resulted provided a situation where Konkombas now have a well organised form of intra-ethnic decision-making process and adjudication of disputes as compared to the previously acephalous and gerontocratic methods. In other words, they have their own chiefs and traditional councils as decision-making machineries in the interest of the Konkomba people.

The ability to undertake independent decision-making with their own chiefs as mouth-pieces of the people now enable them to negotiate with government agencies, NGOs as well as their own internally organised groups on issues of community development (Botchwey, 2006). It also offers the opportunity to contribute to, and benefit from development through their belongingness to other larger ethnic groups at the district or regional levels at a more 
progressive rate than previously (Mahama, 2010). At the same time, the identification of the usefulness of delegated control of authority should have influenced the leadership of the majority tribes to have allowed the Konkomba to implement their decision to have smaller chiefs by some compromise (See Hizkias, 1999). In this way, the tenet of cooperation and reciprocal interaction of the RGCT aids the deduction that the Konkamba would have still preferred to remain under the majority groups, since they are now identified in the decision-making process, and inter and intra-ethnic community development could have been speedier for peaceful co-existence. This could have also prevented the violence and destructions that followed the initial resistance.

\subsection{Strengthening of Inter-ethnic Unity}

This is one of the contradictory effects of conflict because parties are usually torn apart by conflict. However, it is also recognised that when different ethnic groups go through a disturbing conflict experience together, and they are able to resolve it, they experience some sense of cohesion within which they realise what they have lost, and understand each other better. During this phase, they resolve to work hard to prevent a future occurrence of the conflict (Botchwey, 2006). For instance, the constant pressure from the Konkomba and the assessment of the destructive effects of the 1994 Dagomba/Konkomba war, made the Ya Naa of Dagbon to grant the Konkomba their request for paramountcy. Thus, today, the Konkomba are represented in the Northern Regional House of Chiefs, and participate in decision making with their previously antagonistic majority rulers, in matters that affect the interests of all ethnic groups in the region.

\subsection{Group Reformation}

Communities and groups that have gone through conflicts may go through some restructuring (Botchwey, 2006). This might involve environmental, economic and socio-political transformation. Environmentally, violent conflicts usually cause physical destruction to the built environment; apart from the loss of human life and other properties. This usually stimulates efforts to reconstruct houses and other physical infrastructural set ups, sometimes with the support of the government and non-governmental organisations. This may lead to development that corrects inefficiencies in the original conditions and even add what was previously non-existent. For instance, government resettlement schemes after inter and intra ethnic conflicts usually provide victims with houses made of modern materials instead of the original mud houses.

Socio-politically, the concept of acephalous society is now an issue of anachronism in northern Ghana, since previously acephalous groups such as the MO, Konkomba, Kusasi and Sissala have all now adopted the bicephalous system. This shows that the wars of emancipation have been productive (Jacquel, 2007). Thus, conflicts may lead an ethnic group to restructure itself and organise things differently and better than ever.

\subsection{Helping to Redeem the Identity of an Ethnic Group}

Conflicts may help a group to gain recognition. In this situation, an ethnic group may erroneously be considered homogenous and be treated as such (Botchwey, 2006). A case in 
point is the recognition that is currently accorded the Mo, Konkomba and the Kusasi by the government, National and Regional Houses of Chiefs. These groups are now recognised and do participate in many national, regional, district and local level activities as part of an integral whole or independently. This is indicative of ethnic equality without marginalisation. However, the destructive ways by which such were achieved need to be avoided.

\section{Alternative Methods of Preventing Violent and Destructive Inter-Ethnic Conflicts}

The last section of this research explores how to promote conflict prevention and control by the groups involved from a theoretical point of view. Although most inter-ethnic conflicts in northern Ghana ended up being productive with results that tend to establish equilibrium, the high levels of violence and destruction that accompany such conflicts are quite appalling. In particular, this paper argues that the roles of the existing traditional political machinery could be modified for conflict prevention. In other words, the realistic group conflict theory aided explanation of how reciprocity could be established only after conflict has already escalated and perhaps, caused destruction. It is therefore limited, in terms of explaining the prevention of the escalatory and destructive aspects of conflict.

To drive the point home, the House of Chiefs in Ghana, is an assembly of traditional rulers, which has traditional legislative and advisory functions, with branch offices at the district, regional and national levels. It is recognised by the nation as providing a collective voice of the ethnic groups represented, in matters affecting chieftaincy (Republic of Ghana, 2016). Thus, in August 2004, Yagbon-Wura Abudu Bawa Doshie, the President of the Northern Regional House of Chiefs, and King of Gonja land, advocated for the elevation of some ethnic chiefs into paramount chiefs to prevent future conflict (Ghana News Agency, 2004). For instance, in the Gonja traditional area, the Vagla, Hanga, Tapluma, and Mmara, are still under Gonja paramount chiefs, while the Bimoba in the Mamprusi traditional area are also under Mamprusi paramount chiefs, which constitute conditions of latent conflict.

The expression of the need to grant traditional political autonomy to the minority groups is therefore, an indication of the ability to predict the emergence of a greed-grievance conflict between the minority and the majority groups, based on lessons from previous conflicts. The ease of understanding and implementation of the decision of the Yagbon-Wura to grant paramountcy to the minority by all other members of the House could therefore be achievable, if training sessions were incorporated into the roles of the House of Chiefs. For instance, conflict expects could organise workshops on conflict prevention from theoretical perspectives for the chiefs. Buescher (2013), illustrates the possibility of such an intervention by reporting how conflict prevention projects were implemented through community enlightenment on inter-ethnic community dialogue for conflict and violence prevention, access to justice and the rule of law, and more importantly, ensuring that local people know and exercise their rights in order to prevent conflict.

\section{Conclusions and Recommendations}

In conclusion, the Realistic Group Conflict theory has aided the understanding that, inter-ethnic conflicts in northern Ghana are associated with some identified groups, who are 
in competition with each other for power to own and control land as a limited resource, and for the promotion of the identity of minority groups. However, the discussion has shown that the application of the theory in group conflict analysis depicts both negative and positive implications for socio-political development. In other words, conflicts bring about destruction of life and property and impede development activities. On the other hand, some ethnic groups have been able to achieve traditional political autonomy, and the relationships between such groups and the majority groups that previously marginalised them have improved through conflict. The major limitation was that; the adopted realistic group conflict theory could not account for how groups could prevent conflict from escalating into the destructive stage.

There were however, evidences of the ability to identify latent conflicts and the prediction of possible emergence of inter-ethnic conflicts. These in addition to the possibility of conflict prevention programmes through the involvement of communities and the traditional political machinery, motivated the authors to recommend that, the House of Chiefs should incorporate training programmes for its members on matters of potential conflict identification and prevention through seminars and workshops. Expert trainers could then incorporate the theoretical perspectives of conflict development and preventive measures into the programmes. Also, the National Commission for Civic Education, in collaboration with the social media (radio, television and mobile vans fitted with microphones), could be used to enlighten communities prone to conflict about how to resolve their grievances without resorting to violent conflicts. These could protect life and properties and conserve the numerous resources used for conflict management and relief services, for better life supporting development projects, such as health and education.

\section{References}

Acquah, J. G. K. (2006). The judicial role of the chief in democratic governance. In Odotei \&Awedoba, A.K. (eds.) (2006). Chieftaincy in Ghana. Accra: Sub-Saharan Publications.

Apusigah, A. A. (2004). Gender, vulnerability and the politics of decision-making in Ghana: the caseof the Upper East Region. Ghana Journal of Development Studies, 1(2), 6-26.

Akwetey, V. K. (2007). Traditional costumes and their relevanceas cultural symbols to film making in Ghana: Asante case study. A master thesis. Kumasi: Kwame Nkrumah University of Science and Technology.

Awedoba. A. K. (2014). The peoples of northern Ghana. Accra: National Commission on Culture.

Awedoba, A. K. (2010). Living in the age of conflict: exploring the role of indigenous solutions in conflictmanagement and resolution in northern Ghana. In Kendie B.S (ed.) (2010). Proceedings of the 2010 harmattan school: Conflict management and peace building for poverty reduction. Tamale: Center for Continuing Education and Inter-disciplinary Research, University for Development Studies.

Boateng, C. G. (2012). A brief history of northern Ghana-focus on Gonja. Accra: Ghana 
News Agency, September 3, 2012.

Boahene, A. (1970). A thousand years of West African history. In J. F. Ade Ajayi \& I. Espie (eds) (1985).A thousand years of West African history: a handbook for teachers and students. Ibadan: Ibadan University Press.

Botchwey, G. A. (2006). Steps to self reliance: for groups and communities. Cape Coast: Catholic Mission Press.

Brukum, N. J. K. (2001). Overview of ethnic and racial conflicts in Ghana: origins and factors contributing to inter-group violence. A seminar paper. Legon: University of Ghana.

Brukum, N. J. K. (2007). Chieftaincy and ethnic conflicts in the Northern Region of Ghana. In S. Tanah (ed.) (2007). Ethnicity, conflict and consensus in northern Ghana. Accra: WoeliPublishing Services, pp. 98-115.

Buescher, G. S. (2013). Conflict Prevention and Peace Building MDG-F Thematic Study: Review of Key Findings and Achievements. United Nations, MDG Achievement Fund.

Bukari, F. I. M., Aabeyir, R., \& Laari, P. B. (2014). Overview of the influence of natural resource and population distribution on spatial development in Ghana. Journal of Environment and Earth Science, 4(20), 133-148.

Chen, C. (2010). Minority on minority discrimination: impact of majority social norm perception Pittsburgh: Carnegie Mellon University.

Collier, P., \& Hoeffler, A. (2002). Greed and Grievance in civil war. CSAE Working Paper. WPS 2002-01. Oxford: Oxford University.

Collier, P. (2006). Economic causes of civil conflicts and their implications for policy. Oxford: Oxford University.

Collier, P., Hoefflier, A., \& Rohner, D. (2007). Beyond greed and grievance: Feasibility and civil war. World Bank.

Coser, L. (1956). The functions of social conflict. Philadelphia: The Free Press.

Dakuku, K. M. E. (1988). The languages of Ghana. London: Kegan Paul International.

District Capacity Building Project. (2002). Conflict in northern Ghana: a long-standing challenge to poverty-reduction initiative. A discussion paper. Accra: DISCAP.

Donkor, M., \& Mason, J. (1994). Land, paramountcy and conflict in Northern Region: the 1994 guinea fowl war. Accra: CIDA.

Fink, C. F. (1968). Some conceptual difficulties in the theory of social conflicts. Journal of Conflict Resolution, 12, 412-460.

Gad, B. (2003). Communities and law: politics and cultures of legal identities. Michigan: University of Michigan Press.

Galaa, S., \& Bukari, F. I. M. (2014). Water Tariff Conflict Resolution through Indigenous 
Participation in Tri-Water Sector Partnerships: The Case of Dalun Cluster Communities in the Northern Region of Ghana. Development in Practice, 24(5-6), 722-734.

Ganesan, A., \& Vines, A. (2004). Engine of War: Resources, Greed, and the Predatory State. Human Rights Watch, $1^{\text {st }}$ January, 2004 Retrieved May 30, 2014, from http://www.refworld.org/pdfid/402ba8804.pdf

Gati, N. K. (2008). The Dynamics of Communal Conflicts in Ghana's LocalGovernment System: A Case Study of the Adaklu-Anyigbe Conflict. Tromsø: University of Tromsø.

Ghana News Agency. (2004). Pass LI reconstituting NR House of Chiefs - Yagbon-wura. Accra: Ghana News Agency, August 4, 2004.

Ghana Statistical Service. (2008). Ghana living standards survey report of the fifth round. Accra: Ghana Statistical Service.

Ghana Statistical Service. (2012). Population and housing census: special report on urban localities. Accra: GSS.

Ghana Statistical Service (GSS). (2014). Ghana Living Standards Survey Round 6: poverty profile in Ghana. Accra: GSS.

Gonja Youth Association. (2004). Short history of the Gonja Kingdom $\left(6^{\text {th }}\right.$ ed. of the Gonja Youth Congress). Damongo: Gonja Youth Association.

Haverkort, B., Millar, D., \& Gones, C. (2011). knowledge and belief systems in Sub-Saharan Africa. Retrieved April 27, 2014, from http://www.compasnet.org/blog/

Hippolyt, A. S. (2003). Exclusion, association, and violence: trends and triggers in northern Ghana's Konkomba-Dagomba Wars. Chicago: Mid-West Political Science Association.

Hizkias, A. (1999). The meaning of reconciliation. Utrecht: European Center for Conflict Prevention.

Ibrahim, K., \& Isah, M. (2011). Statement: Concern Youth of Wa (Cyw) Reaction. Accra: Ghana News Agency, August 4, 2011.

Jackson, J. W. (1993). Realistic group conflict theory: a review and evaluation of the theoretical and empirical literature. Psychological Record, 43(3), 395-415.

Jacquel, D. S. (2007). What is conflict? Retrieved July 15, 2010, from http://www.ehow/com

Jonson, J. (2007). Overwhelming minority: traditional leadership and ethnic conflicts in Ghana's Northern Region. Oxford: CRISE.

Joshua Project. (2014). Wala, Waali in Ghana. Accra: Joshua Project.

Kagwanja, P., \& Hagg, G. (2007). Identity and peace: reconfiguring conflict resolution in Africa. Durban: Africa Centre for Constructive Resolution of Disputes.

Kangsangbata, C. (2009). Traditional institutions and conflict management in northern Ghana. Tamale: University for Development Studies. 
Kendie, S. B., \& Akudugu, M. A. (2010). Application of game theory in the management of natural resources conflicts: the case of the Bongo District. In B. S. Kendie (ed.) (2010). Proceedings of the 2010 harmattan school: conflict management and peace building for poverty reduction. Tamale: Center for Continuing Education and Inter-disciplinary Research, University for Development Studies.

Kendie, S. B., \& Bukari, K. N. (2012). Conflict and its effects on the development of the Bawku traditional area. University of Cape Coast Journal of Arts and Social Sciences, 1(1), 190-211.

Kumbuor, B. (2002). Customary law of the Dagara" of northern Ghana: indigenous rules or social construction. Journal of Dagaare Studies, 2.

Lentz, C. (2002). Contested boundaries: decentralisation and land conflicts in north-western Ghana. Leiden: Universität Mainz.

Mahama, E. S. (2010). Conflict in Ghana: strategies, stakeholders and the way forward. In B. S. Kendie (ed.) (2010). Proceedings of the 2010 harmattan school: conflict management and peace building for poverty reduction. Tamale: Center for Continuing Education and Inter-disciplinary Research, University for Development Studies.

Mahama, I. (2003). Ethnic conflicts in northern Ghana. Tamale: Cyber Systems.

Martinson, H. B. (1994). The hidden history of Konkomba wars in northern Ghana. Accra: Matter Press.

Macartan, H. (2003). Economics and Violent Conflict. Havard: United Nations Children's Fund.

Matthew, J. (2014). Troop force triple in Ferguson as Obama condemns violence. Yahoo News, November 25, 2014.

Naden, T. (1989). Gur. In Bendor-Samuel, J. 1988. The Niger-Congo languages. 140-168. New York: University Press of America.

Odotei, I. K., \& Awedoba, A. K. (eds.) (2006). Chieftaincy in Ghana: culture governance and development. Legon: Sub-Saharan Publishers, (2006), 17-19.

Odotei, I. K. (2008). History of Ghana. Legon: Institute of African Studies, University of Ghana. Retrieved June 20, 2014, from http://irenekodotei.org/content/history-ghana

Odotei, I. K. (2010). Chieftaincy in Ghana. A presentation during the Go Africa...Go Germany. Programme at the University of Ghana. Retrieved April 27, 2014, from renekodotei.org/content/chieftaincy-ghana

People, J., \& Bailey, G. (2010). Humanity: an introduction to cultural anthropology (9th ed.). California: Wadsworth Cengage Learning.

Republic of Ghana. (2016). Constitution of the Republic of Ghana, chapter twenty-two: chieftaincy. Retrieved December 2, 2016, from 


\section{Macrothink}

International Journal of Social Science Research

ISSN 2327-5510

2017, Vol. 5, No. 1

http://www.ghanaweb.com/GhanaHomePage/republic/constitution.php?id=Gconst22.html

Robinson, J. W. (1972). The management of conflict. The Journal of the Community Development Society, 3(2), 100-105.

Ross, M. H. (2001). Psycho-cultural interpretations and dramas: identity dynamics in ethnic conflict. Political Psychology, 22(1), 157-178.

Schumpeter, J. A. (1950). Capitalism, socialism and democracy (3rd ed.). New York: Harper.

Sherif, M., Harvey, O. J., White, B. J., Hood, W. R., \& Sherif, C. W. (1961). Intergroup conflict and cooperation: The Robbers Cave experiment (Vol. 10). Norman: University Book Exchange.

Sidanius, J., \& Pratto, F. (1999). Social dominance: an intergroup theory of social hierarchy and oppression. Cambridge: Cambridge University Press.

Sulemana, M. (2009). Understanding the causes and impacts of conflicts in the northern region of Ghana. Ghana Policy Journal, 3, 110-139.

Tonah, S. (2012). The politicization of chieftaincy conflict: the case of Dagbon, Northern Region. Nordic Journal of African Studies, 21(1), 1-20.

Tsikata, D., \& Seini, W. (2004). Identities, inequalities and conflicts in Ghana. Oxford: Center for Research on Inequalitity, Human Security and Ethnicity.

United Nations Research Institute for Social Development (2010-2014). Social development in an uncertain world. Geneva: UNRISD.

Zartman, M. (1985/1989). Ripe for Resolution. New York: Oxford University Press.

\section{Copyright Disclaimer}

Copyright for this article is retained by the author(s), with first publication rights granted to the journal.

This is an open-access article distributed under the terms and conditions of the Creative Commons Attribution license (http://creativecommons.org/licenses/by/3.0/). 